\title{
DISCUSSION
}

\section{Laboratory and field studies of response of structures to heave of expansive clay}

\author{
S. N. ABDUlJaUWAD, G. J. Al-SUlaimani, I. A. BASUNBUl and I. AL-BURAIN (1998). \\ Géotechnique 48, No. 1, 103-121.
}

\section{A. D. W. Sparks, University of Cape Town}

The authors are to be congratulated for supplying essential soil properties in their Table 1 . Their values have been reanalysed by a method derived by the writer (Sparks, 1998).

Research workers are aware that they can estimate the water tension in a clay sample by finding the equilibrium water content in a piece of Whatman's No. 42 filter paper which has been in contact with the clay. The same principle is being used in this case, but instead of using a piece of filter paper, the writer uses the initial water content of the clay in order to estimate the initial water tension which exists prior to wetting the clay (Sparks, 1998). One can enter equation (1) with the known initial water content $w_{0} \%$ and the known liquid limit $(\mathrm{LL} \%)$ in order to estimate the original isotropic effective pressure $p_{0}^{\prime}\left(\mathrm{kN} / \mathrm{m}^{2}\right)$ before wetting, or one can use the curves shown in Fig. 1.

The curves in Fig. $1\left(\log p_{0}^{\prime}\right.$ plotted against $\left.w_{0}\right)$ can be described by

$$
\log _{10} p^{\prime}=\frac{16 \mathrm{LL} \%}{\left(1 \cdot 5 \mathrm{LL} \%+w_{0} \%\right)}-5 \cdot 6
$$

where

$p^{\prime}{ }_{0}=$ initial isotropic effective pressure $\left(\mathrm{kN} / \mathrm{m}^{2}\right)$ at $w_{0} \%$ $w_{0} \%=$ initial percentage water content (e.g. prior to wetting) $\mathrm{LL} \%=$ liquid limit of clay (expressed as a percentage)

The shrinkage-swelling curve shows hysteresis when the clay is partly saturated. For example, a saturated sample dries to the same void ratio when it dries to $5 \%$ or $20 \%$ water content; but on wetting, the sample with an initial water content of $5 \%$ swells more than a sample with an initial water content of $20 \%$. In order to take this into account, it is easier to ignore the flattened portions in Fig. 1 of the curves at low water contents. When making swelling predictions, we can use equation (1) to estimate $p^{\prime}{ }_{0}$ for the whole range of water contents, including water contents which are less than $20 \%$.

The heave due to wetting is estimated by using equation (2), in which the value of $p^{\prime}{ }_{0}$ has been estimated from equation (1).

The final value of the equivalent isotropic pressure after wetting is $p_{\mathrm{f}}^{\prime}$. For a weathered shale with horizontal bedding planes, one can assume that the horizontal effective stresses are small compared to the vertical effective stresses during swelling, and for such a clay, one can use $p_{\mathrm{f}}^{\prime}=\left(0.4 p^{\prime}{ }_{\mathrm{v}}-u_{\mathrm{f}}\right)$.

To estimate the heave (e.g. metres):

$$
\text { Heave (metres) }=\frac{\left(1 \cdot 5 \mathrm{LL} \%+w_{0} \%\right)^{2}}{2700 \mathrm{LL} \%} \frac{\left(\log _{10} p^{\prime}{ }_{0}-\log _{10} p_{\mathrm{f}}^{\prime}\right)}{1+0 \cdot 027 w_{0} \%} D_{0}
$$

where

$$
\begin{aligned}
& p^{\prime}{ }_{0} w_{0}, \mathrm{LL} \% \text { are as defined for equation }(1) \\
& p^{\prime}{ }_{\mathrm{v}}=\text { overburden pressure at end of wetting process }\left(\mathrm{kN} / \mathrm{m}^{2}\right) \\
& p^{\prime}{ }_{\mathrm{f}}= \text { final value of equivalent isotropic pressure after } \\
& \text { wetting }=\left(2 \cdot 3 p^{\prime}{ }_{\mathrm{v}}-u_{\mathrm{f}}\right) \text { for weathered igneous rock } \\
& \text { (random orientation), or }=\left(0 \cdot 4 p^{\prime}{ }_{\mathrm{v}}-u_{\mathrm{f}}\right) \text { for weathered } \\
& \text { shale (horizontal bedding and horizontal clay platelets) }
\end{aligned}
$$

Note that the value of $u_{\mathrm{f}}$ is negative, and therefore increases $p_{\mathrm{f}}^{\prime}$

$u_{\mathrm{f}}=$ pore pressure after wetting (usually zero, depends on water table)

$D_{0}=$ the original overall thickness of this elemental soil layer (metres)

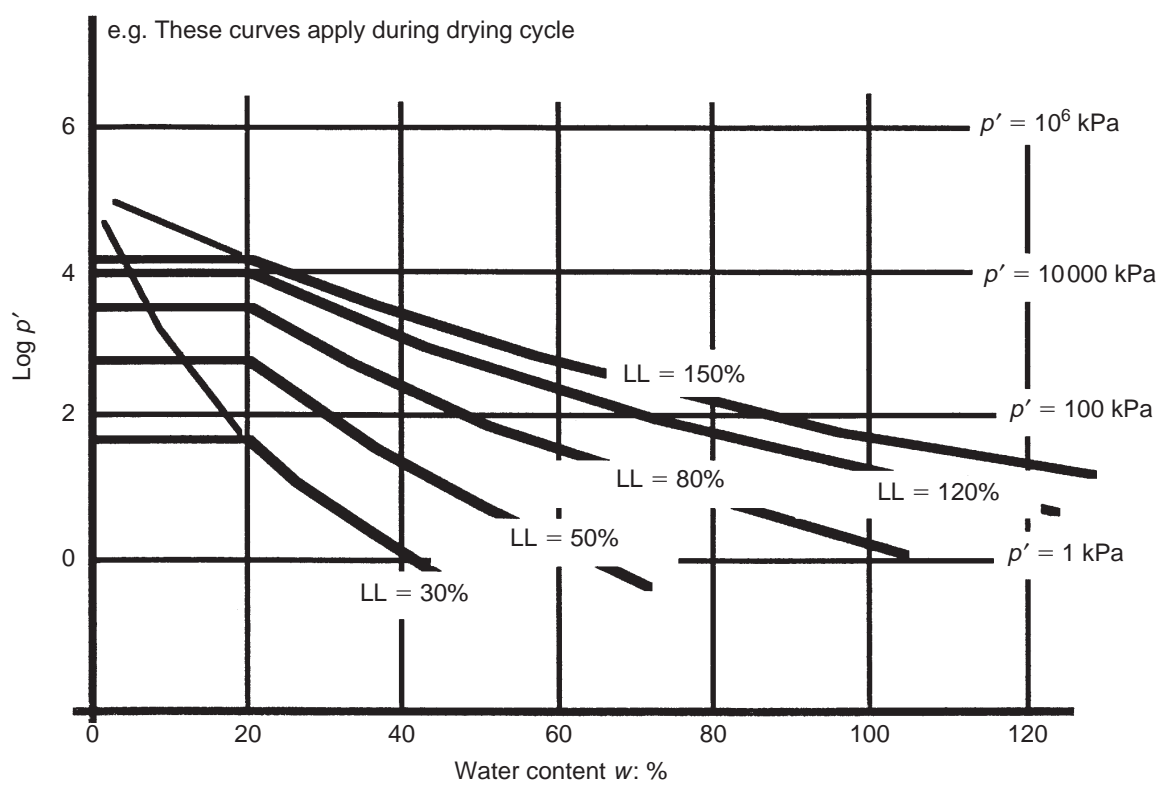

Fig. 1. Effective isotropic pressure $p^{\prime}$ due to $(-u)$. These curves are given by equation (1) 
Table 1. Using formulae (Sparks, 1998) to recalculate original Table 1

\begin{tabular}{|c|c|c|c|c|c|c|c|}
\hline \multirow[t]{3}{*}{ Depth: $\mathrm{m}$} & \multirow{3}{*}{\begin{tabular}{|} 
Liquid limit: \\
$\%$
\end{tabular}} & \multirow{3}{*}{$\begin{array}{l}\text { Initial water } \\
\text { content: } \%\end{array}$} & \multirow{3}{*}{$\begin{array}{l}\text { Initial isotropic } \\
\text { pressure } p_{0}^{\prime}, \\
\text { equation (1): } \mathrm{kPa}\end{array}$} & \multirow{2}{*}{\multicolumn{2}{|c|}{$\begin{array}{c}\text { If final } u \text { linear, and in equilibrium with } \\
\text { water table }\end{array}$}} & \multicolumn{2}{|c|}{ If final $u=0$ for whole profile } \\
\hline & & & & & & \multirow{2}{*}{$\begin{array}{c}\text { Final isotropic } \\
\text { pressure } \\
p_{\mathrm{f}}^{\prime}=0.4 p^{\prime}{ }_{\mathrm{v}} \\
\text { (shale clay): } \mathrm{kPa}\end{array}$} & \multirow{2}{*}{$\begin{array}{l}\% \text { Swelling, } \\
\text { equation }(2)^{*}\end{array}$} \\
\hline & & & & $\begin{array}{l}\text { Final isotropic } \\
\text { pressure } \\
p_{\mathrm{f}}^{\prime}=0.4 p^{\prime}{ }_{\mathrm{v}}-u_{\mathrm{f}} \\
\text { (shale clay): } \mathrm{kPa}\end{array}$ & $\begin{array}{l}\% \text { Swelling, } \\
\text { equation }(2)^{*}\end{array}$ & & \\
\hline $0 \cdot 5$ & 135 & 30 & 4901 & $4+72$ & $14 \cdot 8$ & $4+0$ & $25 \cdot 3$ \\
\hline $1 \cdot 0$ & 131 & 31 & 4104 & $8+67$ & $13 \cdot 8$ & $8+0$ & $21 \cdot 6$ \\
\hline $2 \cdot 0$ & 130 & 35 & 2776 & $16+57$ & $12 \cdot 2$ & $16+0$ & $17 \cdot 4$ \\
\hline $3 \cdot 0$ & 150 & 40 & 2862 & $24+47$ & $13 \cdot 3$ & $24+0$ & $17 \cdot 3$ \\
\hline $4 \cdot 0$ & 100 & 45 & 403 & $32+37$ & $4 \cdot 9$ & $32+0$ & $7 \cdot 0$ \\
\hline $6 \cdot 0$ & 110 & 50 & 386 & $48+17$ & $5 \cdot 1$ & $48+0$ & $6 \cdot 0$ \\
\hline $\begin{array}{c}7 \cdot 7 \text { (permanent } \\
\text { water table) }\end{array}$ & & & & & & & \\
\hline $8 \cdot 0$ & 70 & 50 & 42 & $64-3$ & $-0 \cdot 9$ & $64-3$ & $-0 \cdot 9$ \\
\hline
\end{tabular}

Cumulative heave at soil surface $=64 \mathrm{~cm}=92 \mathrm{~cm}$

${ }^{*}$ Using $C_{\mathrm{s}}=C_{\mathrm{c}} / 4 \cdot 5$ in equation (2).

The value of 2700 in the denominator is based on $C_{\mathrm{s}}=C_{\mathrm{c}} / 4 \cdot 5 ;$ but for $C_{\mathrm{s}}=C_{\mathrm{c}} / 4$, use a value of 2400 instead of 2700

Table 1 shows the recalculated swell values for this soil profile. Only the liquid limit and the original water content are used as starting values in the calculations.

It is gratifying to note that when the percentage swell is plotted against depth, the curve shows zero swell at the existing water table level. In other words, the given values of the liquid limit and water content at the water table level are such that when they are substituted into equation (1) they yield a value of $p^{\prime}{ }_{0}$, which is consistent with the anticipated field value of $p^{\prime}$ at the water table level.

The method used by the writer in Table 1 does not take into account the extra volume of open fissures which must be filled. The cumulative swell values of $64 \mathrm{~cm}$ and $92 \mathrm{~cm}$ at the soil surface are of the same order as those predicted by the authors.
If the swell index is $C_{\mathrm{s}}=C_{\mathrm{c}} / 4$, then these cumulative swells become $72 \mathrm{~cm}$ and $103 \mathrm{~cm}$.

\section{Authors' reply}

The authors would like to thank Professor Sparks for his contribution to their paper for utilizing the soil properties provided in Table 1 of the paper and using it to estimate the heave based on water tension in the clay sample by finding the equilibrium water content in Whatman's No. 42 filter paper.

We would like to thank him for his contribution and we are very happy to know that his finding on the cumulative swell values is in agreement with the values presented in our paper.

\section{REFERENCE}

Sparks, A. D. W. (1998). Stresses in unsaturated soils. Paper submitted to 2nd International conference on unsaturated soils, UNSAT'98, Beijing. 